果を，各ね $1 ， 2 ， 3$ 点に段階をつけて数字化し，合計の 得点数により正。常 (15点, 記号 N), 準正常 (12〜14点, 記号A), 弱小異常 $(9 \sim 11$ 点, 記号 B), 強小異常 (6〜 8 点, 記号C）及び甚しい異常（5点，記号 Cex）之診 定する方式で安る。

5 項目：一般的検査（一般眼科臨休の方式）／着色物 の色調判別／スペクトロスコープで主観的ス ペクトルの完成度/同完全さ/アノマロスコ ープで等色視がいか成立するか。

さらにアノマロスコープ及びスペクトロスコープの設

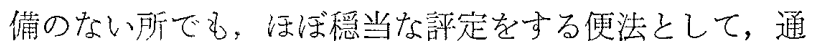
常の一般䠦床で用いる石原式㛟查に実物検查を加えた方 法で，2 点乃至 6 点の間に分布する数字化診定方式をも 提案する。钝は，2点: C, 3 点: $\mathrm{B} \sim \mathrm{C}, 4$ 点: $\mathrm{B}$, 5 点：A，6点：正常とするものである。

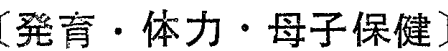

\section{8. 成長期における身体発育について}

栗木秀产，柚木 斉，三浦信雄，長谷部昭久

（日本医大衛生）

すでに私どもは東京都内某小・中学学童抢よび生徒を 対象として，その体力の变遷を2年間にわたって追及し 成長期の発育像学明らかにし，とくに変動の甚だしい時 期に拉ける相刘的重要性を指摘した。今回はそれに加え て，特殊環境下交る成長期の身体発育について，精查 を試み，㐫和世㛟討してみた。即ら，僻地山間部にある 鉱山住宅地区の某小・中学校学音, 生徒をとりあげ, そ の発育の特殊性の因子を解明した。

さらに，私どもが現在との体骨效杲を微祭している自 衛隊体育学校学生について, 詳細な入隊時よりの身体計 测資料を基化して特殊環境下に括ける身体発育の様相を 明らかにし得てので郝告する。

\section{9. 日本人ろ子の身体的諸測度に対する発育学的考察}

臬石 彰, 中川富士 (東邦大衛生公衛)

日本人卒子の身体的䚇測度加，登青学的考察を試及 るために，6才放22才にいたる女子小学生，中学生， 高校生，大学生合計 1,783 名について，生体測定を行な った。

測定項目纯，長育（身長，坐高，下肢長，指極，此坐 高, 比下肢長)，湢育 (体重, 胸囲, 胸廓矢状径, 比体 重, 比胸囲，ローンル係数），栄丵（皮脂厚，上腕囲） である。
1. 女子の身体計測值（身長，体重，胸团，坐高，胸 颜矢状径，下肢長，指極，上腕囲，下腿囲，骨の太さ） の発育曲線は, 発育の早いものは8才〜10才, 発育の利 そいものは10才〜12才ごらに，直線的な思春期の spurt を示し，14才以後，発育速度がゆるやかとなり，完成值 が近づく S 字状曲線の一部を党がく。皮脂厚の発育曲線 は17才〜18才に頂点があり，その後下降する正状の曲線 をえがく。

2. 紿対計測值が完成佰に達する時期には，多少の差 があり，14才〜18才の間である。体の proportion が完 成するのは，比下肢長からみて15才，比胸用和よびロー レル係数からみて17才である。したがって形態測定值全 部が完成するすは18才とい方。

3. 完成值にたい乙，年令別の発育百分率を死ると， 足関節部の骨の太さが大きく，ついで坐高，身長，指極 などの長経や手関節部の貴の太さがはやく，胸囲，上腕 囲，下腿国のような周径や下肢長は沶くれ，体重や皮脂 厚は最手渥い。

4. 発育の個人差をみるため火，各計測值の標準偏差 の年跉别変化をみると，6才〜7才小さく，12才〜14 才間に最大值をとる。その後は小さくなる傾向がある。 発育旺盛時に発育の遇速の差が大きいことがうかがわれ る。各計测僆の变異係数は，梿の大きい皮脂厚，体重の 発青は後天的影響大きく，值の小さい身長，坐高，下肢 長の発育は先天的影響が大きく，他の計測值はこの中間 に位するものと思われる。

\section{0. 成長曲線における女子優越期について}

可次澄产子（実践女子大保健研究室）

わが国に和ける学童の成長の前傾（早期化）は近年著 るしいものがあるが，乙くに㭙代的推移による成長曲線 を钼察すると，年代ごとに少しずつ增大を示している。 男子女子の成長曲線を比倠すると，一時，女子が男子に 管越している時期がある。近年，この時期が少しずつ若 い年令に移動しつつあることが指挞されているが，この 点につき，学校保健統計報告畫の数值により，いささか 解析を試みたので報告する。

(1) 男女の成長曲線を年次的にみると，すでに指墑さ れている如く，発育成長の早要りが見られるが，とくに 昭和35年～36年の数㒹見ると，每年平均 $0.3 \sim 0.6 \mathrm{~cm}$ の増加がみられる。

（2）女子優越期を大正 5 年より昭和 35 年までの推移を 年次別にみると，大正 5 年11.5 13.1才，昭和 5 年11.1 ～13.0才，昭和10年10.7 13.0才，昭和 25 年10.5 13.7 